\title{
The Impact Of Psychological Support On The Stress Level Of Post Partum Mothers During the Covid19 pandemic in the work area of the Lubuk Alung Health Center
}

\author{
Gusma Dewi, Rahmatul Ulya
}

\begin{abstract}
One of the most common psychological problems during the puerperium is the baby blues. Midwives as a place to pour out all their hearts and difficulties in dealing with pregnancy and postpartum. Health workers must be able to recognize the conditions that occur around pregnant women. Good relationships, mutual trust can make it easier for midwives/health workers to provide health education. Anxiety when trying to do an examination of postpartum mothers is often felt by post partum mothers during the corona virus pandemic. The reason is, since Indonesia has been affected by COVID-19, visiting the hospital is not recommended (except in an emergency). The purpose of this study was to determine the impact of psychological support on post partum mothers' stress levels during the Covid19 pandemic. This research method is a Quasi Experimental design with a post test only control group design. Data analysis used the $T$ test to see the effect between the variables studied. The results of the analysis using the $T$ test showed that there was a significant effect of Psychological Support for pregnant women on the stress level of post partum mothers, where $p$-value $<0.05$ with a large $p$-value of 0.00 .
\end{abstract}

Index Terms- Psychological Support, Postpartum Mothers, Stress, Covid-19.

\section{INTRODUCTION}

Mothers who enter the puerperium have several risks to health problems. The postpartum period is the period after childbirth that is needed to restore the reproductive organs to their pre-pregnancy state. Approximately $60 \%$ of maternal deaths due to childbirth and $50 \%$ of deaths occur during the puerperium in the first 24 hours after delivery. During the postpartum period, mothers tend to experience higher fatigue because they have to adjust to new activities and roles as mothers. One of the most common psychological problems during the puerperium is the baby blues ${ }^{1}$.

The problem of baby blues in postpartum mothers can be fatal. Severe psychiatric disorders after childbirth can increase the risk of suicide up to 70 times compared to other causes, especially in the first year after giving birth. More than $50 \%$ in the United Kingdom of women who die by suicide are due to mental disorders after childbirth ${ }^{1}$. The incidence of baby blues in postpartum mothers in Asia, especially in developing countries, is quite high and varies

Gusma Dewi, Faculty of Health Sciences, University of West Sumatra, Lubuk Alung, West Sumatra, Indonesia

Rahmatul Ulya, Faculty of Health Sciences, University of West Sumatra, Lubuk Alung, West Sumatra, Indonesia widely between $26-85 \%$. The incidence of baby blues in postpartum mothers tends to be high and needs serious attention. Almost 50-70\% of women in Indonesia after giving birth are expected to experience the baby blues on the 4th-10th day postpartum. Mothers who experience the baby blues will experience mood swings, feeling sad, anxious, crying often, loss of appetite, and difficulty sleeping (insomnia) $^{2}$.

The cause of the baby blues is the hormone progesterone which has increased since pregnancy, then after giving birth the hormone decreases suddenly so that it affects the physical and emotional state. Baby blues can be categorized as a mild mental disorder syndrome. The condition of the baby blues in mothers is often ignored and is considered the effect of fatigue, so it tends not to be handled properly. Though this condition can be a more severe problem for the mother. Midwives as a place to pour out all their hearts and difficulties in dealing with pregnancy and postpartum. Health workers must be able to recognize the conditions that occur around pregnant women. Good relationships, mutual trust can make it easier for midwives/health workers to provide health education. The role of midwives in providing support includes: through postpartum mother classes, providing opportunities for problematic postpartum mothers for consultation, ensuring that mothers can deal with changes during postpartum, sharing experiences that have been felt by themselves, and deciding what to tell the mother in dealing with problems. new post-partum situation. Midwives also provide education about postpartum care. Usually, the midwife will tell you how to treat stitches. Postpartum mothers were asked not to be afraid to clean the vagina with stitches using running water instead of warm water. The midwife will also notify the mother of the criteria for postpartum blood that is considered normal, which is bright red in the first seven days, brown after seven days, and starts to turn white after two weeks until the postpartum period ends. postpartum mothers will be asked to return to the midwife if the blood is Puerperal remains red after seven days ${ }^{7,8}$.

\section{RESEARCH METHODOLOGY}

\section{A. Research Type and Design}

The design of this study used is a Quasi Experimental design which provides intervention to a group of subjects with or without a comparison group but is not randomized to include subjects in the treatment or control group. The design of this 
The Impact Of Psychological Support On The Stress Level Of Post Partum Mothers During the Covid19 pandemic in the work area of the Lubuk Alung Health Center

study was a post test only control group design, which only intervened in a group with a comparison.

\section{B. Place and time of research}

This research will be carried out in the working area of the Lubuk Alung Health Center in 2021

\section{Population and Sample}

The population is the whole of the object of research. The population of this study were all postpartum mothers in the working area of Lubuk Alung.

The sample of this study used a total sampling technique where the entire population became the research sample with a total sample of 45 people.

\section{Research Instruments and Data Processing}

Research Instruments

The research instrument used was a questionnaire with a guided interview technique and a stress scale assessment.

\section{E. Data processing}

Data analysis used the T test to see the effect between the variables studied.

\section{F. Research variable}

The independent variable in this study is psychological

Tabel 1. Tests of Normality

\begin{tabular}{lccc}
\hline \multicolumn{4}{c}{ Shapiro-Wilk } \\
\hline \multirow{2}{*}{ Stress level } & Statistic & df & Sig. \\
\cline { 2 - 4 } & .954 & 50 & .052 \\
\hline
\end{tabular}

a. Lilliefors Significance Correction

support

The dependent variable in this study is the post partum mother's stress level during the pandemic

\section{RESULT}

\section{A. Assumption Test}

The results of the normality test on the mother's stress level variable using the Statistical Packages for Social Sciences (SPSS) Release 20.00 program, based on the degree of freedom (df) the total sample is 50 so that the normality test uses the Saphiro Wilk Test. Based on the Saphiro Wilk test, the result is 0.52 where $p>0.05$. The results show that the distribution of the distribution is normal (Table 1).

\section{B. Hypothesis Testing}

Based on the results of the normality test, it is known that the data is normally distributed, then it can be continued using the $\mathrm{T}$ test. Hypothesis testing using the one sample $\mathrm{T}$ test is used to determine the truth of the proposed hypothesis. To make it easier to analyze the data through the T test statistical test, it can be seen in the following table:

Tabel 2. One-Sample Test

\begin{tabular}{lccccc}
\hline Group & Df & $\begin{array}{c}\text { Sig. } \\
\text { (2-tailed) }\end{array}$ & $\begin{array}{c}\text { Mean } \\
\text { Difference }\end{array}$ & Lower & Upper \\
\hline $\begin{array}{l}\text { Stress } \\
\text { Level }\end{array}$ & 50 & .000 & 34.16 & 33.29 & 35.03 \\
\hline
\end{tabular}

Based on table 2. It is known that the results of the analysis using the $\mathrm{T}$ test show that there is a significant effect of Psychological Support for pregnant women on the stress level of post partum mothers, where p-value $<0.05$ with a large $\mathrm{p}$-value of 0.00 .

Tabel 3. Group Statistics

\begin{tabular}{lccrr}
\hline Group & N & Mean & Std. Deviation & Std. Error Mean \\
\hline Support & 25 & 31.8800 & 2.43790 & .48758 \\
\hline control & 25 & 36.4400 & 1.50222 & .30044 \\
\hline
\end{tabular}

From table 3. It is known that the total sample in this study was 50 people who were divided into two groups with the number of each sample in the group as many as 25 people. In the table it is also known that there is a difference in the average stress level of the control group with a stress level of 36.44 and the stress level of the group with support of 31.88 . So it can be concluded that there is a decrease in stress in the group that is given psychological support when compared to the group without psychological support.

\section{DiscCustion}

From the results of data analysis, it is known that there is a significant effect between the postpartum mother group with psychological support compared to the control group without psychological support. This is in accordance with research conducted by Hung in 2004 which stated that social support is important for maternal health, both physically and psychologically after the mother gives birth, especially when the mother has a new role as a mother. Another study conducted by Balen and Hermanns (2010) states that mothers who have just had children, that levels of stress, anxiety, and depression will decrease when there is interaction with the closest environment. In the end, the mother will get support and understanding regarding the postpartum blues problem.

Mothers who have just experienced their first pregnancy, of course, need to adjust to some of the changes that occur between pregnancy and childbirth. The changes that occur include carrying out activities and new roles as mothers in the first weeks or even the first months. Some mothers who have difficulty adjusting to their new activities and roles will develop uncomfortable feelings such as feelings of fear, worry, sadness, and feeling alone ${ }^{1}$. Especially if the surrounding environment does not pay attention to the mother and the attention of the people around her is more directed to the baby. The feelings felt by the mother after giving birth, if not treated immediately, the period will be longer and the intensity of uncomfortable feelings will become more frequent. These uncomfortable feelings are the first signs of the postpartum blues ${ }^{4}$. 
Pregnancy and childbirth are a natural process experienced by every woman which in the process is strongly influenced by psychological reactions. The reaction to pregnancy and childbirth experienced by every pregnant woman is different and the reaction is also different, some are worried, afraid, anxious, or even happy ${ }^{3,6}$. Meanwhile, those that affect the emergence of various psychological reactions vary from the pregnant woman, her husband, household and the surrounding environment. This psychological reaction will affect the mother's attitude, behavior, and emotional level. When the mother is unable to exercise effective control over this psychological reaction, there is psychological pressure called stress ${ }^{3}$.

Stress in post-partum mothers often occurs in almost all mothers who have experienced childbirth. Postpartum stress occurs on the first day until the 10th day after delivery which is characterized by feelings of loneliness, anxiety, confusion, restlessness, tiredness, forgetfulness, and unable to sleep. Signs of postnatal stress are early signs of the postpartum blues 5 .

Psychological support from the immediate environment can increase the wife's confidence to be able to reduce the symptoms that lead to the postpartum blues. As research conducted by Hoffnar, Balen and Hermanns (2010) on mothers who have just had children, that levels of stress, anxiety, and depression will decrease when there is interaction with the closest environment. In the end, the mother will get support and understanding regarding the postpartum blues problem.

Women who are pregnant and give birth are characteristics of developmental tasks in young adulthood as stated by Havighurst (in Hurlock, 2019) including starting to raise a family, raising children, and managing a household. In relation to these developmental tasks, women make adjustments in accordance with their new roles through the process of pregnancy and childbirth, namely the roles of being mothers and parents. To be able to become a mother and parent that meets expectations, of course, begins with the mother's adjustment to several conditions that experience changes after giving birth ${ }^{11}$.

Pregnancy and childbirth as described above are natural and normal events, but for some women they can be a period of crisis in a woman's life. This is because at every stage of pregnancy and up to delivery the mother will experience physical and psychological changes so that it is necessary to adjust to these conditions. The definition of adjustment can be viewed from three points of view, namely adjustment as a form of adaptation (adaptation), adjustment as a form of conformity (conformity), and adjustment as an effort to mastery ${ }^{13}$. Adaptation is a process that includes mental and behavioral responses, which is an individual's effort to successfully deal with internal needs, tensions, frustrations, conflicts and produce quality harmony between demands from within the individual and the demands of the outside world or the environment in which the individual lives. is at.

According to Schneiders (1955) a person's self-adjustment can be seen from its aspects, namely 1) personal adjustment is the individual's acceptance of himself. Personal adjustment relates to conflicts, pressures, and circumstances within the individual both physically and psychologically. Individuals who experience obstacles in personal adjustment are characterized by anxiety, feelings of guilt, feelings of dissatisfaction with themselves, 2) social adjustments that occur within the scope of social relations where individuals live and interact.

The same is the case with women who are pregnant and giving birth/maternity. Pregnancy and childbirth are processes of transition and identity as a woman. Women need to adjust to the changes in themselves during pregnancy and childbirth. More clearly, Pieter and Lubis (2010) divide the adjustment phase of postnatal women as follows: 1) the take-in phase, namely the phase where the mother is very dependent on herself, where the mother tells the experience of giving birth repeatedly to everyone, both people around the world. surrounding areas and foreigners who visit the house, 2) the taking hold phase, which is a transitional phase from dependence to independence and lasts for 3-10 days. This phase determines whether the mother can go through the adjustment well or not. When the mother cannot go through this phase, it can cause stress and even postpartum depression, 3) the letting go phase is the phase of accepting responsibility with her new role which lasts for 10 days after giving birth, and 4) the bounding attachment phase is the phase of attachment between mother and child. The third and fourth phases are impossible to achieve when the mother struggles to adjust to the postnatal changes ${ }^{9,10}$.

Women who have experienced the process of childbirth, in this period need help. Psychological support is important for maternal health, both physically and psychologically after the mother gives birth, especially when the mother has a new role as a mother (Hung, 2004). Pierce (in Kail and Cavanaug, 2000) defines psychological support as a source of emotional, informational or assistance from people around individuals who are facing problems and in crisis conditions. This definition is almost the same as that conveyed by Saroson (in Smet, 1994) that psychological support is an interpersonal interaction that aims to provide assistance to someone so that the person concerned feels a form of attention, value, and love.

Based on the opinions of the two experts above, it can be concluded that psychological support is support or assistance given by the closest person to someone who is facing problems so that they feel a form of attention, are appreciated and become part of the group.

This psychological support has a classification in it, as conveyed by Cohen and Syme (1985), namely; (1) Information support, namely providing an explanation of the situation and everything related to the problem being faced by the individual. This support includes providing advice, instructions, input or explanations of how someone behaves. (2) Emotional support, which includes expressions of empathy such as listening, being open, showing trust in what is being complained about, wanting to understand, expressions of affection and concern. Emotional support will make the recipient feel valuable, comfortable, safe, secure, and loved. (3) Instrumental support is assistance that is given directly, in the form of facilities or materials, for example providing the necessary facilities, lending money, providing 
food, games or other assistance. (4) Appraisal or appraisal support, this support can be in the form of a positive assessment, reinforcement (justification) to do something, feedback or showing social comparisons that open the horizons of someone who is in a state of stress ${ }^{14,15}$.

The psychological support needed by postnatal mothers is not only from her husband, but also from her family and the surrounding environment. Due to the fact that other people around this mother also have a role as a stressor. For example, giving advice that tends to forbid mothers not to do this and it becomes a source of stressor in itself. In fact, mothers do not necessarily lack knowledge regarding postnatal care and baby care, so instead of giving a lot of advice or information, it is better to directly provide support in the form of direct assistance $^{13}$.

\section{REFERENCES}

[1] American Psychiatric Association. (2013). Diagnostic and Statistical Manual of Mental Disorders (5th edn), VA: Marecan Psychiatric Publishing Arlington.

[2] Bobak, I.M., Lowdermilk, D.L., \& Jensen, M.D. (2005). Maternity Nursing: Buku Ajar Keperawatan Maternitas Edisi 4, Jakarta: EGC.

[3] Cohen, S. \& Syme, S.L. (1985). Social Support and Health, San Francisco: Academic Press.

[4] Cox, J.L., Holden, J.M., \& Sagovsky, R. (1987). Detection of Postnatal Depression, Developmental of the 10 Aitem Edinburh Postnatal Depression Scale, The British Journal of Psychiatry, 150(6), 782-786.

[5] Henshaw, C. (2003). Mood Disturbance in the Early Puerperium: A Review, Archives of Womens's Mental Health, 6(2), 33-42.

[6] Hoffenar, P.J., Balen, V.F., \& Hermanns, J. (2010). The Impact of Having a Baby on the Level a Content of Woman's Well-being, Soc India Res, 9, 279-295.

[7] Hung, Chich-Hsiu. (2004). Predictors of Postpartum Women's Health Status, Journal of Nursing Scholarship, 36(4), 345-351.

[8] Hurlock, E.B. (1980). Psikologi Perkem-bangan: Suatu Pendekatan Sepanjang Kehidupan, Edisi 5, Jakarta: Erlangga.

[9] Kail, R.V. \& Cavanaug, J.C. (2013). Human Development: A Life-span View, California: Wadsworth Cengage Learning.

[10] McQueen, A. \& Mander, R. (2003). Tiredness and Fatigue in the Postnatal Period, Jounal of Advanced Nursing, 42(5), 463-469.

[11] Nes, R.B., Hauge, L.J., Landolt, M.A., Eskedal, L., Roysamb, E., Kornstad., Irgens., \& Kristensen, P. (2014). Adaptation to the Birth of a Child with Congenital Anomaly: A Prospective Longitudinal Study of Maternal Well-Being and Psychological Distress, Developmen-tal Psychology, 50(6), 1827-1839.

[12] Nichols, M.R., Roux, G.M., \& Harris, N.R. (2007). Primigravid and Multigravida Women: Prenatal Perspectives, The Journal of Perinatal Education, 16(2), 21-32.

[13] Pfuhlmann, B., Stoeber, G., \& Beckmann, H. (2002). Postpartum Psychoses: Prognosis, Risk Factors, and Treatment, Curr Psychiatric 64, 1284-1292.

[14] Pieter, H.Z. \& Lubis, N.L. (2010). Pengan-tar Psikologi untuk Kebidanan, Jakarta: Kencana.

[15] Pilliteri. (2003). Maternal and Child Health Nursing: Care of Childbearing and Childrearing Family, 3rd edition, Lippincott. 